\title{
Analysis of Three Synthese Signals and Roads at Jl. Raya Karang Satria - Bekasi District
}

\author{
Widodo Budi Dermawan dan Putri Oktavian Anwardi \\ Faculty of Engineering, University Mercu Buana Jakarta, Indonesia \\ wbdermawan@gmail.com, poaputri@gmail.com
}

\begin{abstract}
Bekasi Regency is a Regency in West Java Province with a population of $\pm 3,500,023$ Million People (Statistics Indonesia, 2017). J1. Raya Karang Satria - Bekasi Regency is access to the main road to the city border, besides that access to residential locations, schools, which makes vehicle traffic especially during rush hour more congested by the activities on the side of the road such as the ups and downs of passengers from public transportation, as well as vehicles that stop causing long vehicle queues and can reduce travel time. To get primary data that is by surveying traffic volumes, geometric conditions, and environmental conditions. While secondary data obtained by searching using internet media. The analysis data used is guided by the Indonesian Road Capacity Manual Method (MKJI 1997). With this method, the capacity, degree of saturation, delay, and service level at the intersection can be known. From the results of the study obtained the largest degree of saturation (DS) value of 0.95 pcu / hour means that the value exceeds that required by MKJI (1997) which is $<0.75$ from the result of the average intersection delay (D intersection) of the largest $17 \mathrm{sec} / \mathrm{pcu}$. This shows that the level of intersection C service is unstable flow because it has limited speed and movement and therefore it is necessary to review the level of intersection service. And researchers provide an alternative to improve the performance of these unsignalized intersections by changing FRSU from 0.98 to 1 and prohibiting right-turn traffic from both Major D to Minor C and from Minor C to Major B and removing side obstacles. For the road section, the highest degree of saturation (DS) value is obtained 0.74 . This shows that the level of segment service is not stable. So an alternative is done to improve the level of segment performance by removing the original side obstacle factor of 0.86 to 1 on each arm.
\end{abstract}

\section{Keywords}

Unsignalized Intersection, Roads, Degree of Saturation, Delays, Indonesian Road Capacity Manual 1997

\section{Introduction}

Bekasi Regency is a regency in the province of West Java with a population of $\pm 3,500,023$ million inhabitants (Statistics Indonesia, 2017) [1]. Bekasi Regency is a place for developing economic activities which later will equal the city of Jakarta so that the attractiveness for investors to develop economic activities in this district is increasing, this will increase the number of population, the wider area growth. High community mobility will affect the level of traffic density. With the high mobility activities of the community using public vehicles, private vehicles and roads, there will be a movement of traffic flow that causes traffic density.

According to MKJI (1997) [2], Congestion is a condition where the flow of traffic that passes on the road segment that is reviewed exceeds the capacity of the road plan which results in the free speed of the road segment approaching or exceeding $0 \mathrm{~km} /$ hour so that it causes queues. At the time of congestion, the value of the degree of saturation in the road section will be reviewed where the congestion will occur if the value of the degree of saturation reaches more than 0.5. From several locations that have a high level of vehicle density, namely Jl. Raya Karang Satria-Bekasi Regency which is the border access between Bekasi city and Bekasi district where traffic density has increased at the intersection.

Because Jl. Raya Karang Satria-Bekasi Regency is the main road leading to the city border, besides that access to housing locations, schools, which makes vehicle traffic especially during rush hour more congested by the activities on the side of the road such as the ups and downs of passengers from public transport, and vehicles that stop causing long vehicle queues and can reduce travel time. 
This research was conducted at the three-arm unsigned intersection and the Jalan Raya Karang Satria Section of Bekasi Regency, the objects surveyed were light vehicles, motorbikes, heavy vehicles, and non-motorized vehicles. Time for data collection on Wednesday, Friday and Sunday is taken during rush hour ie morning (06.3008-00), afternoon (12.30-13.00), afternoon (16.30-18.00), the analysis used is guided by the Indonesian Road Capacity Manual (MKJI 1997). The stages in the implementation of the study from start to completion of the study are as above.

\section{Result and Analysis}

Based on direct research surveys on unsignalized intersections and roads and the acquisition of data from existing sources and research results on J1.Raya Karang Satria-Bekasi Regency as follows:

\subsection{Performance of Unsignalized Intersections}

\subsubsection{Intersection Geometric Data}

Table 1. Intersection Geometric Data

\section{Jl. Raya Karang Satria - Kabupaten Bekasi}

\begin{tabular}{lc}
\hline The Provice & Kabupaten Bekasi \\
\hline Total Population & $\pm 3,500,023$ Jiwa \\
\hline Road Segment & Jl. Raya Karang Satria \\
\hline Type of area & Local area \\
\hline Intersection Type & 322 and Co $=2700 \mathrm{smp} / \mathrm{jam}$ \\
\hline & 2019, Hours \\
Survey Period & Morning $06.30-08.00 \mathrm{WIB}$, \\
& Noon $11.30-13.00 \mathrm{WIB}$, \\
& Afternoon $16.30-18.00 \mathrm{WIB}$ \\
\hline
\end{tabular}

Source: Research Data, 2019
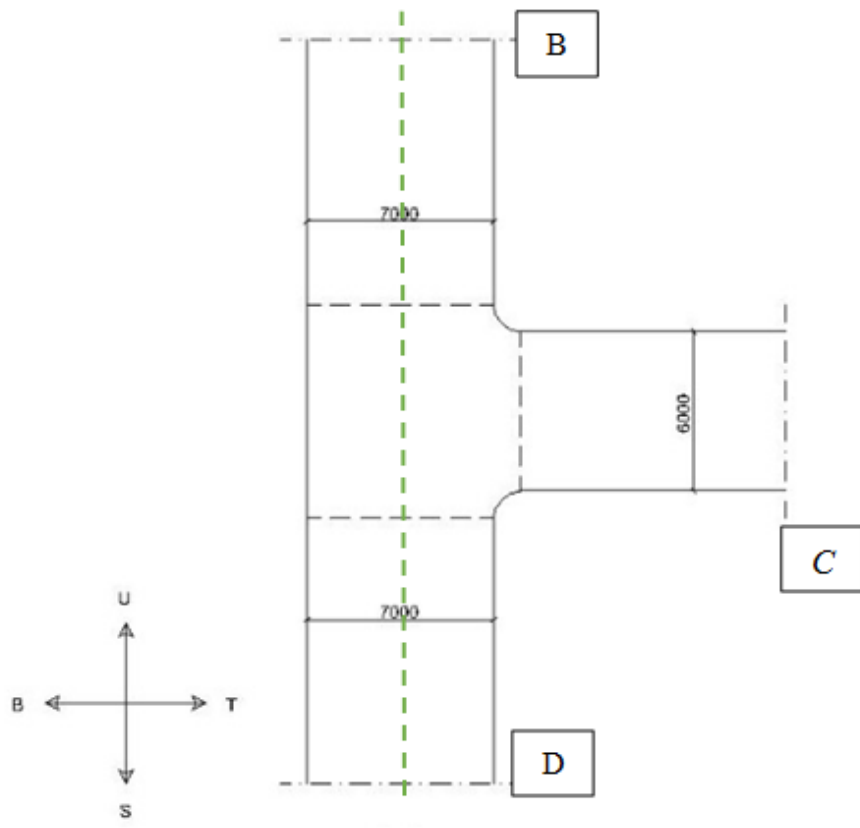

Source: Research Data, 2019

Figure 3. The width of the intersection approach 


\subsubsection{Recapitulation of Intersection Data Results}

Table 2. Recapitulation of Intersection Data Results

\begin{tabular}{|c|c|c|}
\hline \multirow{2}{*}{ Intersection Capacity Components } & \multicolumn{2}{|c|}{ Friday morning } \\
\hline & Existing & Alternative \\
\hline Deviation Type & 322 & 322 \\
\hline Capacity (Co) & 2700 & 2700 \\
\hline Adjustment Width Adjustment $\left(\mathrm{F}_{\mathrm{W}}\right)$ & 0.98 & 0.98 \\
\hline Median Width $\left(\mathbf{F}_{M}\right)$ & 1,00 & $\mathbf{1 , 0 0}$ \\
\hline City Size Adjustments $\left(\mathbf{F}_{\mathrm{CS}}\right)$ & 1,00 & $\mathbf{1 , 0 0}$ \\
\hline Kend Ratio Not Motorized With Kend & 0,007 & $\mathbf{0 , 0 0 7}$ \\
\hline Side Barriers $\left(\mathbf{F}_{\mathrm{RSU}}\right)$ & 0,98 & $\mathbf{1 , 0 0}$ \\
\hline Left Turn Ratio $\left(\mathbf{P}_{\mathrm{LT}}\right)$ & 0,41 & $\mathbf{0 , 5 1}$ \\
\hline Left Turn Adjustment $\left(\mathbf{F}_{\mathrm{LT}}\right)$ & 1 & 1,26 \\
\hline Right Turn Ratio $\left(\mathbf{P}_{\mathrm{RT}}\right)$ & 0,24 & $\mathbf{0 , 0 0}$ \\
\hline Turn Adjustment $\left(\mathrm{F}_{\mathrm{RT}}\right)$ & 0,87 & 1.09 \\
\hline Minor Road Ratio $\left(\mathbf{P}_{\mathrm{MI}}\right)$ & 0,35 & $\mathbf{0 , 0 0}$ \\
\hline MinorTraffic Flow Ratio Minor Roads $\left(\mathrm{F}_{\mathrm{MI}}\right)$ & 0,92 & $\mathbf{0 , 9 2}$ \\
\hline Intersection Capacity (smp/hour) C & 2081.00 & 3353.00 \\
\hline Traffic Flow (smp/hour) & 1981 & 1980 \\
\hline of Saturation (DS) & 0,95 & $\mathbf{0 , 5 9}$ \\
\hline Intersection Traffic Delay (det/smp) & 13 & 6,00 \\
\hline Major Traffic Delays (det/smp) & 9,50 & 4,50 \\
\hline Minor Traffic Delays (det / smp) (det/smp) & 19,56 & $\mathbf{8 , 8 1}$ \\
\hline Intersection Geometric Delay (det/smp) & 4,00 & $\mathbf{4 , 0 0}$ \\
\hline Delay Delay (det/smp) & 17,00 & 10,00 \\
\hline Queue Opportunities (\%) & $71,77-36,36$ & $31,20-14,69$ \\
\hline LOS Goal & $\mathbf{C}$ & B \\
\hline
\end{tabular}

Source: Research Data, 2019

The alternative is to change $\mathrm{F}_{\mathrm{RSU}}$ from a value of 0.98 to 1 and prohibit the flow of traffic that will turn right from the Major D to Minor C road or from Minor C to Major B and eliminate side obstacles.

We can see the results of calculations based on the alternatives below, the degree of saturation is less than 0.75 , namely $\mathrm{DS}=0.59$.

So the value of the level of road service obtained is B with a degree of Saturation (DS) $\leq 0.75$.

\subsection{Performance of Roads}

\subsubsection{Geometric Road Segments}

Observations were made at 1 point on Jl. Raya Karang Satria - Bekasi Regency. The survey for the road section was taken from a 300-meter intersection to the south. Data obtained through direct observations and surveys in accordance with the existing conditions of the road section on Jl Raya Karang Satria - Bekasi Regency. 
Table 10. Geometrik Ruas Jalan

Geometric Conditions of Roads

\begin{tabular}{lc}
\hline & Geometric Conditions of Roads \\
\hline \multirow{2}{*}{ Road Facilities } & \multicolumn{2}{c}{ Jl. Raya Karang Satria } \\
\cline { 2 - 3 } & Direction Mutiara Gading $\quad$ Direction Ganda Agung \\
\hline
\end{tabular}

Figure

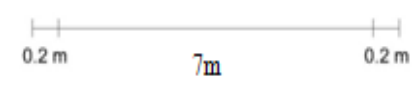

\begin{tabular}{lcc}
\hline Road Type & $2 / 2$ UD & $2 / 2$ UD \\
\hline Sidewalk Width & None & None \\
\hline Road Shoulder & $<0,2$ & $<0,2$ \\
\hline Median & None & None \\
\hline Road Marks & None & None \\
\hline Types of Pavement & Asphalt & Asphalt \\
\hline
\end{tabular}

Source: Research Data, 2019

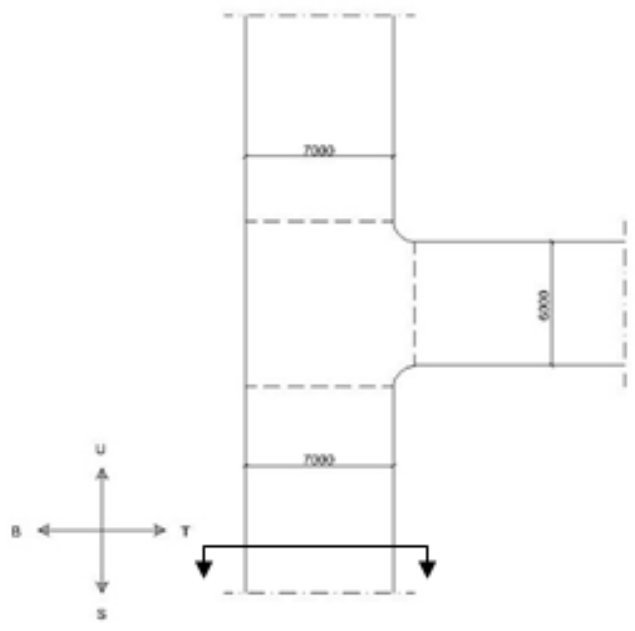

Source: Research Data, 2019

Figure 6. Direction of traffic flow on roads

\subsubsection{Recapitulation Of Roads}

Table 20. Recapitulation of Roads

\begin{tabular}{lccc}
\hline \multicolumn{1}{c}{ Information } & \multicolumn{2}{c}{ Jl. Raya Karang Satria (South) } \\
\cline { 2 - 4 } Co = Two lanes not divided & Time & Existing & Alternative \\
\hline & Morning & 2900 & 2900 \\
& Noon & 2900 & 2900 \\
\hline & Afternoon & 2900 & 2900 \\
\hline $\mathbf{F C}_{\mathbf{w}}=$ Two lanes not divided, effective lane width $\mathbf{2 m} \mathbf{7 m}$ & Morning & 1 & 1 \\
& Noon & 1 & 1 \\
\hline & Afternoon & 1 & 1 \\
$\mathbf{F C}_{\mathbf{S P}}=$ Dua lajur 2/2 UD SP 50\% - 50\% & Morning & 1 & 1 \\
& Noon & 1 & 1 \\
\hline
\end{tabular}




\begin{tabular}{|c|c|c|c|}
\hline \multirow{4}{*}{$\begin{array}{l}\mathrm{FC}_{\mathrm{SF}}=\text { Medium side barrier class, effective shoulder width } \\
<0.5 \mathrm{~m}, 2 / 2 \mathrm{UD}\end{array}$} & \multicolumn{2}{|c|}{$\begin{array}{l}\text { ME } 2 \mid \text { NUMBER } 3 \mid \mathrm{M} \\
\text { ne at http://proceedings. wor } \\
\text { ISSN: } 2656-1174 \text { (online) }\end{array}$} & $\begin{array}{l}2020 \\
\text { nferenc }\end{array}$ \\
\hline & Morning & 0.86 & 1 \\
\hline & Noon & 0.86 & 1 \\
\hline & Afternoon & 0.86 & 1 \\
\hline & Morning & 1.04 & 1.04 \\
\hline FCcs $=$ Total Population 3,500,023 People & Noon & 1.04 & 1.04 \\
\hline & Afternoon & 1.04 & 1.04 \\
\hline & Morning & 1333.90 & 1333.90 \\
\hline Peak hour volume (Q) smp/hour & Noon & 1702.40 & 1702.40 \\
\hline & Afternoon & 1920.70 & 1920.70 \\
\hline & Morning & 2593.76 & 3016.00 \\
\hline Road capacity (C) smp/hour & Noon & 2593.76 & 3016.00 \\
\hline & Afternoon & 2593.76 & 3016.00 \\
\hline & Morning & 0.51 & 0.44 \\
\hline The degree of saturation $Q / C$ & Noon & 0.66 & 0.56 \\
\hline & Afternoon & 0.74 & 0.64 \\
\hline & Morning & A & $\mathrm{A}$ \\
\hline Level Of Service (LOS) & Noon & B & A \\
\hline & Afternoon & $\mathrm{C}$ & $\mathrm{B}$ \\
\hline & Morning & 14.57 & 53.07 \\
\hline Survey Speed (km/hour) & Noon & 43.23 & 43.05 \\
\hline & Afternoon & 43.38 & 43.49 \\
\hline
\end{tabular}

Source: Research Data, 2019

From the results of the analysis a solution will be tried to improve the performance of the Section by removing the original side obstacle factor of 0.86 by changing the FCSF side obstacle factor in each arm to 1.

\section{Conclussion}

Based on the survey results of intersection vehicles and road sections in the analysis that has been done, it can be concluded as follows:

\subsection{Unsignalized Intersections}

- At unsignalized intersections, the condition based on traffic flow at peak hours is Friday, July 21, 2019 at $06.30-08.00 \mathrm{WIB}$, showing the volume of intersections $=1,981 \mathrm{smp} /$ hour with an intersection capacity $=2,081$. then the degree of saturation (DS) is obtained as much as 0.95 , meaning that the value exceeds that required by MKJI 1997, which is $<0.75$, from the results of the average intersection delay the intersection delay is $17 \mathrm{sec} /$ junior high. In order to get the Level of Service (LOS) / LOS C level, which means the current speed is not stable.

- Alternatives that can be used to overcome moderate congestion and service level values to match the requirements of the MKJI 1997, include changing the FRSU from a value of 0.95 to 1 and prohibiting the flow of traffic that will turn right from either Major D to Minor C and Minor C to Major B as well as eliminating side barriers and obtained the Degree of Saturation (DS) to 0.59 this is included in the figures required by the MKJI 1997, which is $<0.75$ with the result of an average delay of $10 \mathrm{det} / \mathrm{smp}$ and LOS B values.

\subsection{Road Section}

- On the Karang Satria highway segment the direction of ivory pearl of the highest volume of vehicles was obtained on Friday, June 21, 2019 at 17:45 to 18:00 West Indonesia Time ie 3,218 smp/hour with an average actual speed of $43.11 \mathrm{~km} /$ hour. The value of saturation degree (Q / C) obtained for the performance of the Karang Satria toll road section at peak hours is obtained on Friday at 16.30-18.30 
with the degree of saturation (DS) $=0.74$ with LoS C service level, this shows that the segment the road exceeds the 1997 MKJI requirement which should be $<0.75$.

- $\quad$ From the results of the analysis, solutions will be tried to improve the performance of Jl. Raya Karang Satria - Bekasi Regency by removing the original side barrier factor of 0.86 by changing the $\mathrm{FC}_{\mathrm{SF}}$ side obstacle factor on each arm to 1 .

\section{References}

Bekasi Regency Statistics Agency (BPS). (2017). Bekasi Regency in Figures 2017. Bekasi Regency: BPS Bekasi Regency.

Directorate General of Highways (1997). Indonesian Road Capacity Manual (MKJI). Bina Karya. Jakarta.

\section{Biographies}

Putri O. Anwardi is a student of the Faculty of Civil Engineering at Mercu Buana University in 2015 and successfully completed her undergraduate education in February 2020. Putri works in a property development company in East Jakarta with a position as project administration staff. The last educational background is a drawing of building techniques in 2013.

Widodo B. Dermawan is a Practitioner as well as a Lecturer in Civil Engineering, especially in the field of Transportation, he took Strata 1 at Parahyangan Catholic University, and took his Masters at the University of Wisconsin-Madison. In the world of education, he teaches at Mercu Buana University, Jakarta. 